\title{
Arsenic Removal from Groundwater by Household Sand Filters - Comparative Field Study, Model Calculations, and Health Benefits
}

Michael Berg ${ }^{1, *}$, Samuel Luzi ${ }^{1}$, Pham Thi Kim Trang ${ }^{2}$, Pham Hung Viet $^{2}$, Walter Giger ${ }^{1}$, and Doris Stüben ${ }^{3}$

${ }^{1}$ Eawag, Swiss Federal Institute of Aquatic Science and Technology, Ueberlandstrasse 133, CH-8600 Dubendorf, Switzerland

${ }^{2}$ Center for Environmental Technology and Sustainable Development (CETASD), Hanoi University of Science, 334 Nguyen Trai, Hanoi, Vietnam

3 Institute for Mineralogy and Geochemistry, University of Karlsruhe, Kaiserstrasse 12, D-76128 Karlsruhe, Germany

* Corresponding author. Phone: +41-44-823 50 78; Fax: +41-44-823 5028

E-mail: michael.berg@eawag.ch

Key words

Arsenic removal, manganese removal, drinking water, sand filter, co-precipitation, hydrous ferric iron, exposure mitigation, Vietnam, Bangladesh

Contents

Text SI 1 Study Area

Text SI 2 Measures to Prevent Microbial Activity in Sand Filters

Text SI 3 Water Sampling and Sample Treatment

Text SI 4 Chemical Analysis and Quality Assurance

Text SI 5 Considerations for Disposal of used Sand

Figure SI 1 Map of Vietnam and the Hanoi area pinpointing the investigated villages

Figure SI 2 Correlation between $\mathrm{Mn}$ and Ca removal

Figure SI 3 Correlation between arsenic and phosphate removal

Table SI 1 Sampling and treatment of samples

Table SI 2 Composition of artificial groundwater used for co-precipitation experiments

Table SI 3 Fitted sorption constants $\left(K_{d}\right)$

Table SI 4 Estimated SF arsenic removal for Bangladesh, including median and average concentrations of $\mathrm{As}, \mathrm{Fe}, \mathrm{Mn}$, and $\mathrm{P}$.

\section{Literature Cited}




\section{Experimental Section}

\section{Text SI 1:}

Study Area. This field study was conducted in three villages located in the Red River Delta, namely Thuong Cat, Hoang Liet and Van Phuc (see Figure SI 1a). A total number of 43 SFs were investigated in households pumping groundwater with elevated arsenic levels CP experiments were conducted with the same 43 groundwaters as well as with water collected from 31 additional tubewells. With highly variable concentrations of As (10-382 $\mu \mathrm{g} / \mathrm{L}), \mathrm{Fe}$ $(<0.1-48 \mathrm{mg} / \mathrm{L}), \mathrm{P}(<0.01-3.7 \mathrm{mg} / \mathrm{L})$, and $\mathrm{Mn}(0.05-3.3 \mathrm{mg} / \mathrm{L})$, the investigated wells represent a broad and representative range of groundwater composition (see Figure SI 1b and database of Supporting Information). Tube well depths at the investigated sites were in a range of 10-100 $\mathrm{m}$ (average and median $38 \mathrm{~m}$ ). Groundwater is predominantly extracted from the quaternary sediment layers that are divided in a Holocene aquifer (10-45 m) with fine clay and sand, and a Pleistocene aquifer $(30-70 \mathrm{~m})$ containing coarse material. More information on geology and climate is documented in $(1,2)$.
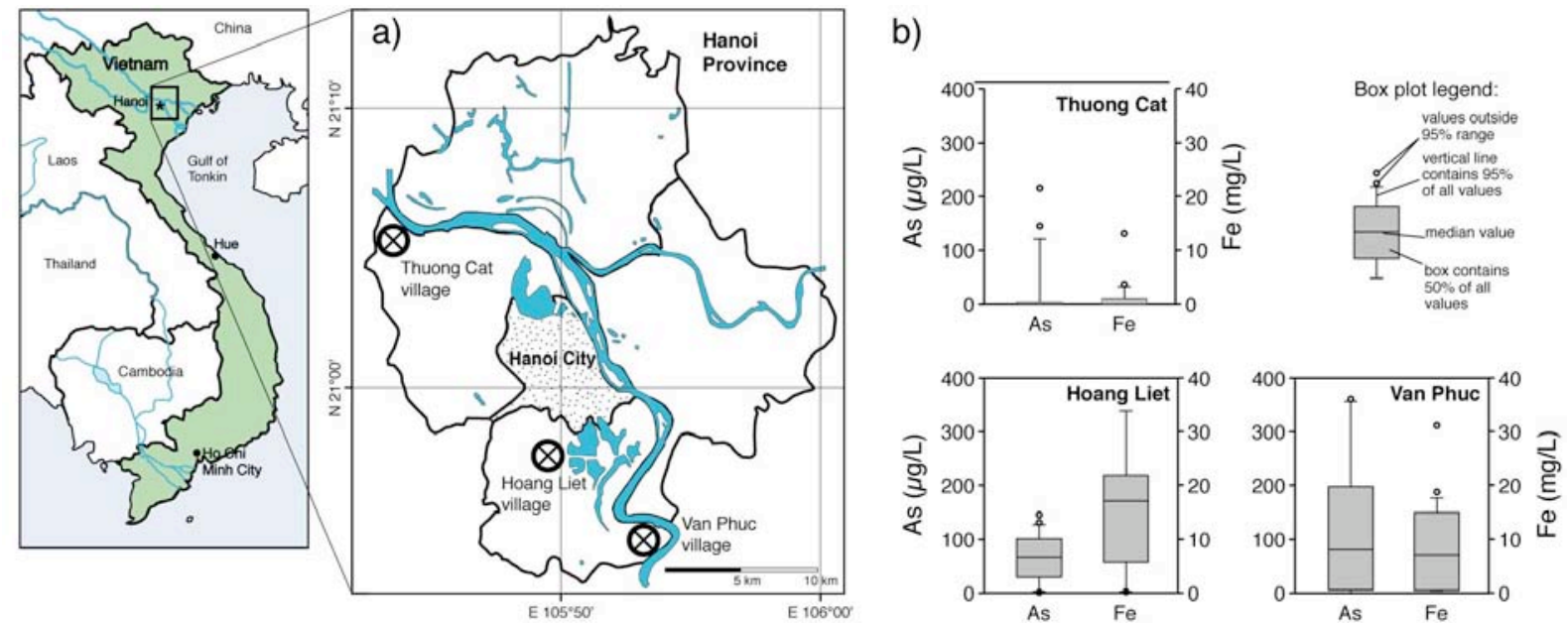

FIGURE SI 1. a) Map of Vietnam and the Hanoi area pinpointing the villages where sand filters were evaluated. b) Box plots depicting the broad variability of iron, phosphate, and arsenic concentrations in the groundwaters included in this study. 


\section{Text SI 2:}

Measures to Prevent Microbial Activity in Sand Filters. Similar to the microbial activity in aquifers, which eventually leads to the release of arsenic into the groundwater, bacteria can also influence the processes of arsenic removal in sand filters. Since bacteria are ubiquitous in the environment, colonisation of a sand filter by microorganisms is only a matter of time if the living conditions are favourable. The organic material, on which bacteria feed, can either get into the filter as dissolved organic matter (DOM) or fall into the tank as dirt, dust, leaves, dead insects, etc. Degradation of organic material by microorganisms depletes the oxygen, thereby hampering the arsenic removal efficiency. Measures to inhibit microbial activity in the sand filter tank are therefore important and include: i) complete drainage of the water from the filter tank after each batch of treatment, which is achieved by placing the water outlet at the very bottom of the filter (see Figure 5); ii) covering the sand compartment with a lid to prevent the influx of solid organic material (e.g., leafs or insects); iii) regular exchange of the filter sand; and iv) removal of microbial colonies by thorough cleaning and brushing of the filter walls every time the sand is exchanged.

\section{Text SI 3:}

Water Sampling and Sample Treatment. Two field campaigns were conducted for this study in September (1st campaign) and in December 2002 (2nd campaign). Groundwater temperature and $\mathrm{pH}$ (SensIon1, Hach), dissolved oxygen and redox potential (MX300, Mettler-Toledo), and conductivity (EcoScan con5, EUTECH instruments) were recorded onsite. Samples for lab analysis were taken after stabilization of the oxygen and redox values (typically after 3-5 minutes of pumping). Sampling position, description, total number and treatment of samples, as well as analyzed parameters are summarized in Table SI 1. Samples B and C were filtered (0.45 $\mu \mathrm{m}$ cellulose nitrate) on-site before acidification. Samples B, D and $\mathrm{E}$ were acidified with $1 \% \mathrm{HNO}_{3}$ to a $\mathrm{pH}<2$ in order to prevent precipitation of solid 
phases. A subset of samples was acidified to $\mathrm{pH} 4$ for As(III) analysis. Samples D were filled in $500 \mathrm{~mL}$ PET bottles for CP experiments, and the open bottles exposed to air for 72 hours (1st campaign) or 24 hours (2nd campaign). The precipitates from samples D were filteredoff $(0.45 \mu \mathrm{m})$ and the water acidified to $\mathrm{pH}<2$. All samples were filled into pre-washed $(\mathrm{HCl}$ and distilled water) PET bottles, and stored at $4{ }^{\circ} \mathrm{C}$ in the dark until analysis.

\begin{tabular}{|c|c|c|c|c|c|c|c|}
\hline code & $\begin{array}{l}\text { sampling } \\
\text { position }^{\mathrm{a}}\end{array}$ & $\begin{array}{l}\text { sample } \\
\text { description }\end{array}$ & volume & treatment & preservation & parameters & no. of samples \\
\hline A & (1) tube well & $\begin{array}{l}\text { groundwater } \\
\text { not acidified }\end{array}$ & $500 \mathrm{~mL}$ & no & no & $\begin{array}{l}\mathrm{HCO}--, \mathrm{Cl}- \\
\text { SO42-, DOC }\end{array}$ & 74 \\
\hline B & (1) tube well & $\begin{array}{l}\text { groundwater } \\
\text { acidified }\end{array}$ & $200 \mathrm{~mL}$ & filtration & $\mathrm{pH}<2$ & $\begin{array}{l}\mathrm{As}_{\mathrm{tot}}, \mathrm{Fe}, \mathrm{Mn}, \mathrm{Na} \\
\mathrm{K}, \mathrm{Mg}, \mathrm{Ca}, \mathrm{P}, \mathrm{Si}\end{array}$ & 74 \\
\hline C & (1) tube well & $\begin{array}{l}\text { groundwater for } \\
\text { As(III) analysis }\end{array}$ & $50 \mathrm{~mL}$ & filtration & $\mathrm{pH} 4$ & As(III) & 10 \\
\hline D & (1) tube well & $\begin{array}{l}\text { groundwater for } \\
\text { co-precipitation }\end{array}$ & $200 \mathrm{~mL}$ & aeration & no & $\begin{array}{l}\mathrm{As}_{\mathrm{tot}} \\
(\mathrm{Fe}, \mathrm{Mn}, \mathrm{Mg}, \mathrm{Ca} \\
\mathrm{P}, \mathrm{Si})^{\mathrm{b}}\end{array}$ & $\begin{array}{l}74 \\
(31-52)^{b}\end{array}$ \\
\hline$E$ & (2) storage tank & sand-filtered water & $200 \mathrm{~mL}$ & no & $\mathrm{pH}<2$ & $A s_{\text {tot }}, P, \mathrm{Si}$ & 43 \\
\hline$F$ & (3) filter outlet & sand-filtered water & 200 mL & no & $\mathrm{pH}<2$ & $A s_{\text {tot }}, P, S i$ & $16^{\mathrm{C}}$ \\
\hline
\end{tabular}

\section{Text SI 4:}

Chemical Analysis and Quality Assurance. All chemicals used for sample preservation and analysis were purchased from Fluka (Switzerland) and Merck (Switzerland) in the highest available quality. Concentrations of total $\mathrm{Fe}, \mathrm{Mn}, \mathrm{Na}, \mathrm{K}, \mathrm{Mg}$, and $\mathrm{Ca}$ were measured by atomic absorption spectroscopy (Shimadzu AA-6800, Kyoto, Japan). Total As in water and in hair was measured by the same AAS instrument coupled to a hydride generation device (HGAAS). Silicate and phosphate concentrations were determined photometrically by the molybdate blue method. Metals, $\mathrm{Si}$ and $\mathrm{P}$ in raw groundwater were all analyzed in the acidified water samples. As(III) was determined in 10 samples acidified after filtration $(0.45$ $\mu \mathrm{m}$ cellulose nitrate) in the field to $\mathrm{pH} 4$, using HG-AFS in the citrate mode as described by 
Hug and Leupin 2003 (3). DOC was measured by thermal-catalytic oxidation (highTOCII, Elementar, Germany). Arsenic removal was only determined for households using groundwater with initial As concentrations $>10 \mu \mathrm{g} / \mathrm{L}$. The full database of measured groundwater constituents is also available as Supporting Information.

The quality of chemical and instrumental analysis was assured by parallel measurements at CETASD (Vietnam) and EAWAG (Switzerland). Linear regression of EAWAG and CETASD results produced the following coefficients of determination $\left(r^{2}, n=74\right)$ : As (0.95), Fe (0.97), Mn (0.99,), Ca (0.99), Mg (0.98), P (0.97), and, Si (0.96). To further ensure the quality of the measurements, recoveries were determined before every sample series in certified water samples (SPS-SW1, Merck VI standard). Recoveries were in the range of 95$106 \%(\mathrm{As})$ and $93-104 \%(\mathrm{Fe}, \mathrm{Mn})$. As determined in certified reference hair (NCS ZC 81002) was less than $2 \%$ deviating from the certified value of $0.59 \mu \mathrm{g} / \mathrm{g}$. DOC concentrations were only determined at EAWAG.

\section{Text SI 5:}

Considerations for Disposal of used Sand. Any arsenic pumped with groundwater eventually ends up in the terrestrial environment, regardless whether it is concentrated on sand or co-precipitation sludge, or consumed with drinking water. The immediate surrounding of an openly running tubewell as well as its sewage must therefore be considered a pollution point source. Sludge from household co-precipitation tanks is usually disposed and discarded in the backyard, posing a threat to vegetation and people. In contrast, sand filters concentrate As over a long time period on sand that is replaced and more mindfully handled than co-precipitation sludge. However, in the worst case assuming that $100 \mathrm{~kg}$ of sand is used to treat $30.000 \mathrm{~L}$ of groundwater containing $500 \mu \mathrm{g} / \mathrm{L}$ arsenic, the As levels in sand can reach $150 \mathrm{mg} / \mathrm{kg}$. It is therefore important to handle used sand with care. Arsenic 
does not leach in oxic environments and ambient $\mathrm{pH}$. The old sand can thus be used for construction, or be stored in dedicated areas. The disposal into flowing water of large rivers is also discussed, but the long-term impact of doing so needs to be thoroughly assessed. Locations to be avoided for sand dumping are ponds which can become anoxic, as well as gardens, vegetable fields and irrigated fields, because anoxic conditions at the plant roots (4) could lead to an accumulation of As in agricultural products.

\section{Model Calculations.}

\begin{tabular}{|lll|}
\hline \multicolumn{3}{|c|}{ Table SI 2. Composition of artificial groundwater used for co- } \\
precipitation experiments (5) \\
\hline $\mathrm{As}(\mathrm{V})$ & 500 & $\mu \mathrm{g} / \mathrm{L}$ \\
$\mathrm{As}(\mathrm{III})$ & 500 & $\mu \mathrm{g} / \mathrm{L}$ \\
$\mathrm{As}(\mathrm{III}+\mathrm{V})$ & $250+250$ & $\mu \mathrm{g} / \mathrm{L}$ \\
$\mathrm{Fe}(\mathrm{II})$ & $1-50$ & $\mathrm{mg} / \mathrm{L}$ \\
$\mathrm{PO} 4$ & $0-3$ & $\mathrm{mg} / \mathrm{L}$ \\
$\mathrm{SiO} 4$ & $0-30$ & $\mathrm{mg} / \mathrm{L}$ \\
$\mathrm{pH}$ & 7.0 & \\
$\mathrm{pH}$
\end{tabular}

Table SI 3. Fitted sorption constants ( $\mathrm{K}_{d}$ 's) published in (5) and used in this study for the modeling of theoretical arsenic removal by coprecipitation

$\begin{array}{ll} & \log \mathrm{K}_{d} \\ \mathrm{As}(\mathrm{V}) & 5.7 \pm 0.25 \\ \mathrm{As}(\mathrm{III}) & 3.7 \pm 0.15 \\ \mathrm{P} & 5.9 \pm 0.15 \\ \mathrm{Si} & 2.8 \pm 0.10\end{array}$




\section{Results and Discussion}

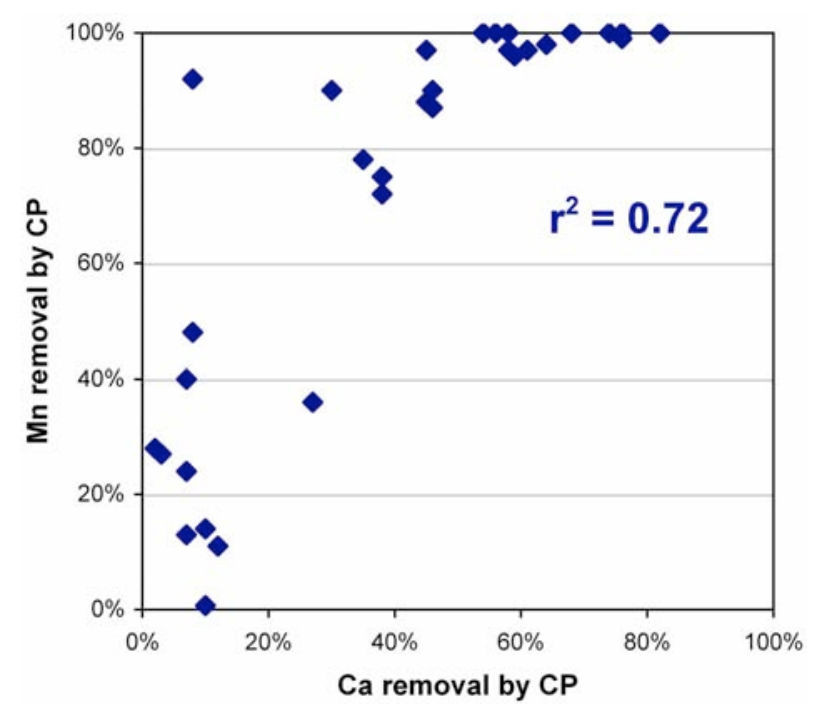

Figure SI 2. Correlation between $\mathrm{Mn}$ and Ca removal $\left(r^{2}=0.72\right)$, indicating that $\mathrm{Mn}$ might have co-precipitated with Ca carbonate.

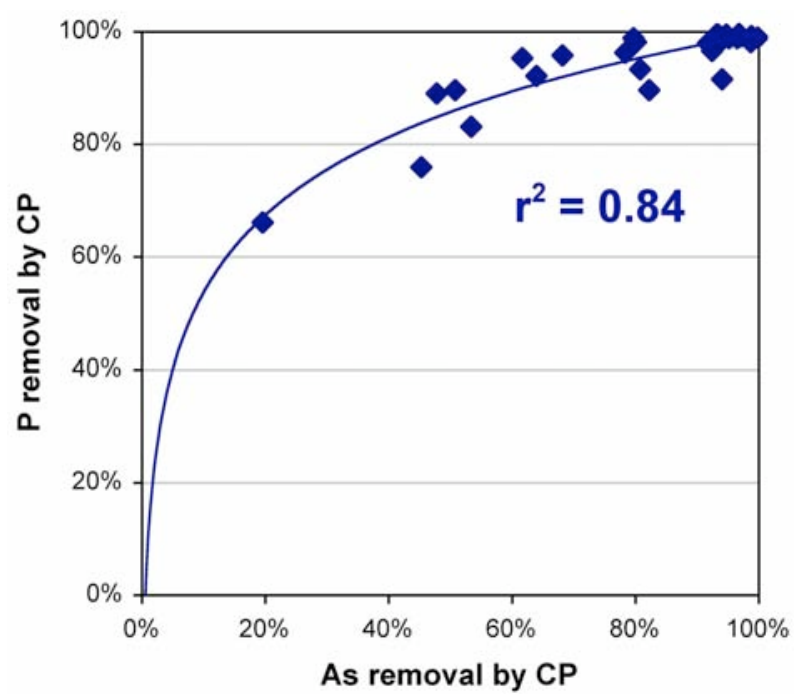

Figure SI 2. Correlation between arsenic and phosphate removal $\left(r^{2}=0.84\right.$, logarithmic). Groundwaters exhibiting less than $0.25 \mathrm{mg}$ phosphate-P per liter were neglected because corresponding concentrations determined after phosphate removal were mostly below detection limit, resulting in high uncertainties of removal rates. 
TABLE SI 4. Estimated SF arsenic removal ${ }^{\mathrm{a}}$ for $^{\text {Bangladesh }}{ }^{\mathrm{b}}$ as well as measured (meas.) and estimated (est.) values for Vietnam, including median and average concentrations of $\mathrm{As}, \mathrm{Fe}, \mathrm{Mn}$, and $\mathrm{P}$.

scenarios for

groundwater composition

\section{Bangladesh $(n=1493)$}

As $>10^{\mathrm{d}}$, Fe $0-1^{\mathrm{e}} \quad 23516 \%$

As $>10, \mathrm{Fe}>1$

As $>10, \mathrm{PO} 4<2 \mathrm{e}, \mathrm{Fe}>1$

As $>10, \mathrm{PO} 4<2, \mathrm{Fe}>5 \quad 527 \quad 35 \%$

As $>10, \mathrm{PO} 4<2$, $\mathrm{Fe}>10 \quad 234 \quad 16 \%$

\section{Vietnam $(n=43)$}

\section{As $>10^{\mathrm{d}}$, Fe $0-1^{\mathrm{e}}$}

As $>10, \mathrm{Fe}>1$

As $>10, \mathrm{PO} 4<2^{\mathrm{e}}, \mathrm{Fe}>1$

As $>10, \mathrm{PO} 4<2, \mathrm{Fe}>5$

$37 \%$

$4093 \%$

$3786 \%$

$3070 \%$

As $>10, \mathrm{PO} 4<2, \mathrm{Fe}>10$
As removal by SF $(\%)$ residual As after SF $(\mu \mathrm{g} / \mathrm{L})$

\begin{tabular}{|c|c|c|c|c|c|c|c|c|c|c|c|c|}
\hline \multicolumn{2}{|c|}{ average } & \multirow{2}{*}{$\frac{\text { median }}{\text { meas. est. }}$} & \multirow{2}{*}{$\begin{array}{l}\text { average } \\
\text { meas.est. }^{a}\end{array}$} & \multirow{2}{*}{$\frac{\text { median }^{\text {meas.est. }^{a}}}{}$} & \multirow{2}{*}{$\begin{array}{c}\text { Fe / As ratio } \\
\text { av.med. }\end{array}$} & \multirow{2}{*}{$\begin{array}{c}\text { As }(\mu \mathrm{g} / \mathrm{L}) \\
\text { av.med. }\end{array}$} & \multirow{2}{*}{\multicolumn{2}{|c|}{$\begin{array}{r}\mathrm{Fe}(\mathrm{mg} / \mathrm{L}) \\
\text { av. med. }\end{array}$}} & \multirow{2}{*}{\multicolumn{2}{|c|}{$\begin{array}{l}\text { PO4-P (mg/L } \\
\text { av. med. }\end{array}$}} & \multirow{2}{*}{\multicolumn{2}{|c|}{$\begin{array}{r}\mathrm{Mn}(\mathrm{mg} / \mathrm{L}) \\
\text { av. med. }\end{array}$}} \\
\hline neas & $e s t^{a}$ & & & & & & & & & & & \\
\hline & $36 \%$ & & 70 & 28 & $\begin{array}{ll}5 & 11\end{array}$ & 108 & 0.5 & 0.5 & 1.42 & 0.50 & 0.53 & \\
\hline & $70^{\circ}$ & & 39 & 25 & $49 \quad 64$ & 13272 & 6.5 & 4.6 & 1.29 & 1.00 & 0.63 & \\
\hline & $71 \%$ & $67 \%$ & 36 & 22 & 5575 & 127 & 7.0 & 5.2 & 0.85 & 0.80 & 0.74 & 0.4 \\
\hline & 78 & 75 & 30 & 17 & 82130 & 134 & 11.0 & 9.1 & 0.94 & 0.90 & 0.82 & \\
\hline & $82 \%$ & $81 \%$ & 20 & 10 & 136269 & 110 & 15.0 & 14.0 & 0.97 & 0.90 & 1.00 & 0.6 \\
\hline
\end{tabular}

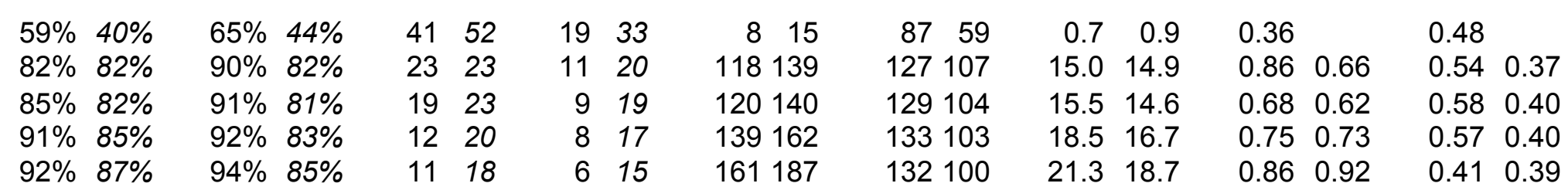

a Calculated with equation (4). ${ }^{\mathrm{b}}$ Samples with As concentrations $>10 \mu \mathrm{g} / \mathrm{L}$ from database published in (6). ${ }^{\mathrm{c}}$ Measured average and median groundwater concentration. ${ }^{d} \mu \mathrm{g} / \mathrm{L} .{ }^{e} \mathrm{mg} / \mathrm{L}$. 


\section{Literature Cited}

(1) Berg, M.; Tran, H. C.; Nguyen, T. C.; Pham, H. V.; Schertenleib, R.; Giger, W. Arsenic contamination of groundwater and drinking waiter in Vietnam: A human health threat. Environ. Sci. Technol. 2001, 35, 2621-2626.

(2) Duong, H. A.; Berg, M.; Hoang, M. H.; Pham, H. V.; Gallard, H.; Giger, W.; von Gunten, U. Trihalomethane formation by chlorination of ammonium- and bromide-containing groundwater in water supplies of Hanoi, Vietnam. Water Res. 2003, 37, 3242-3252.

(3) Hug, S. J.; Leupin, O. Iron-catalyzed oxidation of arsenic(III) by oxygen and by hydrogen peroxide: $\mathrm{pH}-\mathrm{dependent}$ formation of oxidants in the Fenton reaction. Environ. Sci. Technol. 2003, 37, 2734-2742.

(4) Norra, S.; Berner, Z. A.; Agarwala, P.; Wagner, F.; Chandrasekharam, D.; Stuben, D. Impact of irrigation with As rich groundwater on soil and crops: A geochemical case study in West Bengal Delta Plain, India. Appl. Geochem. 2005, 20, 1890-1906.

(5) Roberts, L. C.; Hug, S. J.; Ruettimann, T.; Billah, M.; Khan, A. W.; Rahman, M. T. Arsenic removal with iron(II) and iron(III) waters with high silicate and phosphate concentrations. Environ. Sci. Technol. 2004, 38, 307-315.

(6) BGS and DPHE "Arsenic contamination of groundwater in Bangladesh," BGS Technical Report WC/00/19; British Geological Survey: Keyworth, U.K., 2001. www.bgs.ac.uk/arsenic/bangladesh 